\title{
UCHWAŁA SEJMIKU WOJEWÓDZTWA PODEJMOWANA NA PODSTAWIE ART. 96 USTAWY PRAWO OCHRONY ŚRODOWISKA
}

\section{REGIONAL ASSEMBLY RESOLUTION ADOPTED PURSUANT TO ARTICLE 96 OF THE ACT ON ENVIRONMENTAL PROTECTION LAW}

\author{
http://dx.doi.org/10.12775/PPOS.2015.018
}

\section{STRESZCZENIE}

Przedmiotem niniejszego opracowania jest próba analizy art. 96 Ustawy z dnia 27 kwietnia 2001 r. Prawo ochrony środowiska ${ }^{1}$ $\mathrm{w}$ aspekcie praktycznego zastosowania tego uregulowania w Polsce wobec podjęcia przez Sejmik Województwa Małopolskiego Uchwały z dnia 25 listopada 2013 r. nr XLIV/703/13 w sprawie określenia

* Magister, asystent w Katedrze Prawa Górniczego i Ochrony Środowiska na Wydziale Prawa i Administracji Uniwersytetu Śląskiego w Katowicach.

1 T. j. Dz.U. z 2013 r., poz. 1232 z późn. zm., dalej cyt.: u.p.o.ś. 
rodzajów paliw dopuszczonych do stosowania na obszarze Gminy Miejskiej Kraków. Ponadto praca zawiera w swej treści odwołanie do Wyroku Wojewódzkiego Sądu Administracyjnego w Krakowie w sprawie sygn. akt: II SA/Kr 490/14², który to został wydany na skutek zaskarżenia ww. uchwały. Opracowanie w swej treści zawiera także odniesienie do projektowanych zmian art. 96 u.p.o.ś.

\section{Słowa kluczowe}

Prawo ochrony środowiska; ochrona powietrza; paliwa.

\section{ABSTRACT}

The object of this publication is the analysis of Article 96 of the Act of 27 April 2001 on Environmental Protection Law in terms of practical application of this legislation in Poland compared with Lesser Poland Regional Assembly adopting the resolution of 25 November 2013 no. XLIV/703/13 on determining the types of fuels approved for use in the area of the Municipality of Cracov. In addition, the paper includes a reference to the judgment of the Regional Administrative Court in Cracov on the ref. Act II SA/Kr 490/14 which was passed as a result of the appeal of the above-mentioned resolution. The paper also contains a reference to the proposed changes to Article 96 of the Environmental Protection Law Act.

\section{Keywords}

Environmental protection law; air protection; fuels.

Jednym z instrumentów prawnych służących ochronie powietrza przed zanieczyszczeniami jest ten przewidziany $\mathrm{w}$ art. 96 Ustawy z dnia 27 kwietnia 2001 r. Prawo ochrony środowiska. Rozwiązania prawne wynikające z powołanej regulacji zostały zastosowane po raz pierwszy w Polsce przez Sejmik Województwa Małopolskiego w Uchwale z dnia 25 listopada 2013 r. nr XLIV/703/13, w sprawie określenia rodzajów paliw dopuszczonych do stosowania na obszarze Gminy Miejskiej Kra-

2 http://orzeczenia.nsa.gov.pl/doc/DE375EC66D

[dostęp: 03.03.2015 r.] 
ków. W związku ze wspomnianą uchwałą przed Wojewódzkim Sądem Administracyjnym w Krakowie (w sprawie sygn. akt: II SA/Kr 490/14) toczyło się postępowanie sądowo-administracyjne zainicjowane przez mieszkanki Krakowa w trybie art. 90 Ustawy o samorządzie województwa ${ }^{3}$ w zw. z art. 101 Ustawy o samorządzie gminnym ${ }^{4}$, które zakończyło się stwierdzeniem nieważności ww. uchwały. Tematyka ta wydaje się być ważka ze względu na co najmniej kilka okoliczności. Po pierwsze tak innowatorskie rozwiązanie na szczeblu regionalnym, które może być przykładem do naśladowania dla innych jednostek samorządu terytorialnego, potrzebuje wyczerpujących, transparentnych, niebudzących wątpliwości (przede wszystkim natury konstytucyjnej) podstaw prawnych, których w obecnym polskim systemie prawa niestety brak. Po wtóre niemałe znaczenie mają niepokojące wyniki raportu Najwyższej Izby Kontroli w zakresie kontroli ochrony powietrza przed zanieczyszczeniami ${ }^{5}$. Po trzecie ochrona i poprawa jakości powietrza (jako elementu

3 T. j. Dz.U. z 2013 r. poz. 596 z późn. zm.: 1. Każdy, czyj interes prawny lub uprawnienie zostały naruszone przepisem aktu prawa miejscowego, wydanym w sprawie z zakresu administracji publicznej, może - po bezskutecznym wezwaniu organu samorządu województwa, który wydał przepis, do usunięcia naruszenia - zaskarżyć przepis do sądu administracyjnego.

4 T. j. Dz.U. z 2013 r. poz. 594 z późn. zm.

5 W ocenie Najwyższej Izby Kontroli organy władzy publicznej działają nieskutecznie w sferze ochrony powietrza, nie zapewniając dostatecznej ochrony ludzi i środowiska naturalnego przed negatywnymi skutkami jego zanieczyszczenia. W kontrolowanym okresie w dalszym ciągu nie były dotrzymywane normy jakości powietrza przyjęte w ustawodawstwie Unii Europejskiej, a implementowane do krajowego porządku prawnego. Świadczą o tym pomiary wykonywane przez inspekcję ochrony środowiska oraz sporządzane na ich podstawie okresowe oceny jakości powietrza. Wskazują one, że największy problem dla jakości powietrza w skali kraju stanowiły ponadnormatywne stężenia pyłu PM10 oraz benzo(a)pirenu, których głównym źródłem była tzw. niska emisja. W latach 2010-2013 przekroczenia poziomów normatywnych pyłu PM10 w skali kraju występowały w ponad 75\% wszystkich stref, w których dokonuje się oceny jakości powietrza, a w przypadku benzo(a)pirenu w około $90 \%$ stref. Wskazuje to, że dotychczasowe tempo i skala działań naprawczych podejmowanych przez organy publiczne są niewystarczające do osiągnięcia wymaganej jakości powietrza. Informacja o wynikach kontroli, Ochrona powietrza przed zanieczyszczeniami, 01.12.2014 r., http://www.nik. gov.pl/plik/id,7764,vp,9732.pdf [dostęp: 03.03.2015 r.] 
środowiska) zostały przyjęte jako jeden z priorytetów działania resortu ochrony środowiska na rok $2015^{6}$. Artykuł ten skupi się na analizie aktualnie obowiązującej treści art. 96 u.p.o.ś., jak również odniesie się do projektu poselskiego przedłożonego w lutym 2015 r. ${ }^{7}$ dotyczącego zmiany art. 96 u.p.o.ś.

Na wstępie należy poczynić kilka uwag ogólnych zauważając, że omawiana regulacja została umieszczona w u.p.o.ś w Tytule II (Ochrona zasobów środowiska), Dziale II (Ochrona powietrza), a jej brzmienie jest następujące: „Sejmik województwa może, w drodze uchwały, w celu zapobieżenia negatywnemu oddziaływaniu na środowisko lub na zabytki określić dla terenu województwa bądź jego części rodzaje lub jakość paliw dopuszczonych do stosowania, a także sposób realizacji i kontroli tego obowiązku". Jak wynika z przytoczonego przepisu, unormowanie to jest niezwykle syntetyczne - można zaryzykować nawet stwierdzenie - ubogie w treści i zawiera się w jednej jednostce redakcyjnej ustawy ${ }^{8}$.

Organem kompetentnym do podjęcia przedmiotowej uchwały jest wyłącznie sejmik województwa9 ${ }^{9}$. Jest to uprawnienie tego organu, które - z perspektywy jego dotychczasowego niewykorzystywania w polskiej praktyce - powinno zostać ocenione jako instrument o charakterze doraźnym czy też wy-

6 https://www.mos.gov.pl/artykul/7_aktualnosci/24223_powietrze_w_ centrum_uwagi_ruszaja_konsultacje_krajowego_programu_ochrony_powietrza.html [dostęp: 28.03.2015 r.]

7 Projekt poselski zmian p.o.ś. z lutego 2015 r. http://orka.sejm.gov.pl/ Druki7ka.nsf/Projekty/7-020-1250-2015/\$file/7-020-1250-2015.pdf [dostęp: 09.03.2015 r.]

8 Tu należy podkreślić, że w takiej zwięzłej redakcji art. 96 u.p.o.ś. WSA w Krakowie w uzasadnieniu do Wyroku w sprawie II SA/Kr 490/14 podnosi, że: „pozorna skrótowość regulacji nie oznacza błędu, lecz celowy zabieg ograniczający sięganie po określony instrument prawny stanowiący wielowymiarową ingerencję w obowiązujący system i porządek prawny".

9 Uprzednio obowiązujący art. 96 przewidywał, że: „wojewoda może, w drodze rozporządzenia, w celu zapobieżenia negatywnemu oddziaływaniu na środowisko lub na dobro kultury określić dla terenu województwa lub jego części rodzaje lub jakość paliw dopuszczonych do stosowania, a także sposób realizacji i kontroli tego obowiązku" (Ustawa z dnia 27 kwietnia 2001 r. Prawo ochrony środowiska, tekst pierwotny Dz.U. z 2001 r., nr 62, poz. 627). 
jątkowym. Dokonując analizy wyżej wymienionego uregulowania, w pierwszej kolejności należy zważyć, że ustawodawca nie określił charakteru prawnego uchwały podejmowanej przez sejmik województwa na mocy ww. przepisu - brak tu bowiem określenia czy moc prawna tej uchwały stanowi rangą akt prawa miejscowego, czy też akt prawa wewnętrznego ${ }^{10}$. Przyjąć jednak należy, opierając się tu na dorobku orzecznictwa ${ }^{11}$, że uchwała wydana w oparciu o art. 96 u.p.o.ś. jest aktem prawa miejscowego ${ }^{12}$.

$\mathrm{Na}$ tle takiej konstrukcji omawianego przepisu podkreślić wypada szeroko zakreślony cel uzasadniający podjęcie tej uchwały. Akt ten może mieć na celu nie tylko zapobieżenie negatywnemu oddziaływaniu na środowisko (w tym - zgodnie z art. 3 pkt 11 u.p.o.ś. - także oddziaływaniu na zdrowie ludzi), ale również na zabytki ${ }^{13}$. Co równie istotne, owo negatywne od-

10 Problem ten został zauważony w literaturze przedmiotu. Z. Bukowski, Możliwości prawne wprowadzenia zakazu spalania określonych paliw stałych na terenie gminy, „Studia z zakresu prawa, administracji i zarządzania UKW” 2012, t. 1, s. 45-46, jak również w przedłożonym projekcie zmian z lutego 2015 r. dot. u.p.o.ś. przez posła T. Arkita.

11 Por. Wyrok NSA z dnia 18 lipca 2006 r., sygn. akt: I OSK 669/06 („Dla kwalifikacji danego aktu jako prawa miejscowego znaczenie decydujące ma charakter norm prawnych i kształtowanie przez te normy sytuacji prawnej adresatów. W przypadku bowiem uznania, że uchwała zawiera przynajmniej jedną normę postępowania o charakterze generalnym i abstrakcyjnym jest ona aktem prawa miejscowego") czy Wyrok WSA w Białymstoku z dnia 2 lutego 2006 r., sygn. akt: II SA/Bk 681/05 („Charakter generalny posiadają normy, które określają adresata poprzez wskazanie jego cech, nie zaś poprzez wymienienie z imienia (nazwy). Abstrakcyjność normy polega na tym, że jej dyspozycja określająca postępowanie adresata ma zastosowanie w wielu, powtarzalnych okolicznościach, nie zaś w jednej konkretnej sytuacji”).

12 Por. Z. Bukowski, op. cit., s. 49.

13 Ustawa z dnia 23 lipca 2003 r. o ochronie zabytków i opiece nad zabytkami (t. j. Dz.U. z 2014 r. poz. 1446 z późn. zm.) w art. 3 pkt 1 zabytek definiuje jako nieruchomość lub rzecz ruchomą, ich części lub zespoły, będące dziełem człowieka lub związane z jego działalnością i stanowiące świadectwo minionej epoki bądź zdarzenia, których zachowanie leży w interesie społecznym ze względu na posiadaną wartość historyczną, artystyczną lub naukową. Ponadto ustawa w art. 3 pkt 2 i 3 rozróżnia zabytek nieruchomy i ruchomy stanowiąc, że zabytkiem nieruchomym jest nieruchomość, jej część lub zespół nieruchomości, o których mowa w pkt 1, zaś zabytek ruchomy to rzecz ru- 
działywanie na środowisko czy na zabytki nie musi zachodzić łącznie, albowiem z brzmienia ww. unormowania expressis verbis wynika alternatywa w tym zakresie.

Treść art. 96 u.p.o.ś. nie określa temporalnego zakresu obowiązywania uchwały. Właściwym wydaje się jednak przyjęcie, że uchwała ta winna mieć charakter jedynie okresowy i w sytuacji, gdy negatywne oddziaływanie na środowisko czy też zabytki przestanie mieć miejsce należałoby ją uchylić ${ }^{14}$. W odniesieniu do terytorialnego obowiązywania przepis art. 96 u.p.o.ś. przewiduje możliwość podjęcia takiej uchwały dla terytorium całego województwa lub jedynie jego części. Tu jednak należy mieć na uwadze, aby dokonanie różnicowania zasięgu obowiązywania uchwały miało miejsce po gruntownym rozważeniu stanu faktycznego ${ }^{15}$.

Treść art. 96 u.p.o.ś. in fine wskazuje na pewne elementy uchwały, jakie winna zawierać, a mianowicie: rodzaje lub jakość paliw dopuszczonych do stosowania, a także sposób realizacji i kontroli tego obowiązku. Jak wynika z powyższego, przepis dopuszcza prawną możliwość alternatywnego ujęcia w uchwale bądź rodzajów paliw, bądź ich jakości, co jednak nie wyklucza zastosowania w uchwale charakteru mieszanego tj. zawarcia w jej treści dla określonych paliw ich rodzajów, a dla innych ich jakości ${ }^{16}$. Kwestią problematyczną, powstającą na tle ww. regulacji, jest określenie rodzajów paliw w uchwale, gdyż nie jest do końca wiadome, w jakim znaczeniu ustawodawca posłużył się pojęciem „paliwa”. W pierwszej kolejności na gruncie polskiego ustawodawstwa należy odwołać się do definicji „paliwa” wynikającej z Ustawy z dnia 10 kwietnia 1997 r. Prawo energetyczne ${ }^{17}$. Zgodnie bowiem $\mathrm{z}$ art. 3 pkt 3 powołanej ustawy paliwami są paliwa stałe, ciekłe i gazowe będące nośnikami ener-

choma, jej część lub zespół rzeczy ruchomych, o których mowa w pkt 1 art. 3 ustawy.

14 Zob. Bukowski, op. cit., s. 52.

15 Ibidem. Gruntowne rozważenie stanu faktycznego miałoby na celu m.in. uniknięcie zarzutu nierównego traktowania obszarów o podobnym stopniu czy przyczynach zanieczyszczenia powietrza.

16 Ibidem, s. 53.

2/2015 17 T. j. Dz.U. z 2012 r. poz. 1059 z późn. zm. 
gii chemicznej ${ }^{18}$. Inną definicję „paliwa” zawiera Ustawa z dnia 25 sierpnia 2006 r. o systemie monitorowania i kontrolowania jakości paliw ${ }^{19}$, która to $\mathrm{w}$ art. 2 ust. 1 pkt 3 statuuje, że paliwa to paliwa ciekłe, biopaliwa ciekłe lub inne paliwa odnawialne, gaz skroplony (LPG), sprężony gaz ziemny (CNG), skroplony gaz ziemny (LNG), lekki olej opałowy, ciężki olej opałowy oraz olej do silników statków żeglugi śródlądowej. Odnotować wypada, że w doktrynie odnaleźć można stanowisko wedle którego rozumienie paliwa na potrzeby art. 96 u.p.o.ś. winno być stosowane w ujęciu potocznym ${ }^{20}$. Według tego poglądu możliwym byłoby więc dopuszczenie całych kategorii paliw do stosowania, czego następstwem byłoby uniemożliwienie stosowania innych kategorii paliw (np. dopuszczenie paliw ciekłych i gazowych, a niedopuszczenie paliw stałych), co oczywiście musiałoby mieć swoje szczegółowe uzasadnienie w ramach konkretnego przypadku $^{21}$. Przywołać należy także stanowisko odmienne wskazujące, że na tle omawianej regulacji paliwa winny być rozumiane zgodnie z definicją zawartą $\mathrm{w}$ art. 3 pkt 3 Ustawy o systemie monitorowania i kontrolowania jakości paliw ${ }^{22}$.

Poruszając zaś kwestię związaną ze sposobem realizacji obowiązku wskazanego w uchwale należałoby przyjąć, że - wobec określania przez uchwałę rodzaju paliw lub jakości paliw dopuszczonych do stosowania - sposobem realizacji tego obowiązku jest nakaz stosowania dopuszczonych, bądź ze względu na rodzaj bądź ze względu na jakość, paliw ${ }^{23}$.

Treść przepisu art. 96 u.p.o.ś. nie uszczegóławia co należy rozumieć pod pojęciem sposób kontroli, posługując się jedynie przytoczonym już lapidarnym określeniem. Na marginesie wspomnieć należy o sankcji prawnej z art. 334 u.p.o.ś. zgodnie

18 Z. Bukowski uważa, że trudno przyjąć, iż jest to definicja paliwa, a raczej jest to tylko kategoryzacja paliw w związku z ich stanem skupienia. Z. Bukowski, op. cit., s. 53.

19 T. j. Dz.U. z 2014 r. poz. 1728.

20 Z. Bukowski, op. cit., s. 53-54.

21 Ibidem.

22 M. Górski, M. Pchałek, W. Radecki, J. Jerzmański, M. Bar, S. Urban, J. Jedrośka, Prawo ochrony środowiska. Komentarz, Warszawa 2011, s. 373.

23 Z. Bukowski, op. cit., s. 55. 
z którym: „Kto nie przestrzega ograniczeń, nakazów lub zakazów, określonych w uchwale sejmiku województwa przyjętej na podstawie art. 96, podlega karze grzywny". Wykroczenie to ma charakter formalny i powszechny. Powołany powyżej zapis ustawowy nie wymaga stwierdzenia skutku w postaci rzeczywistego zagrożenia środowiska lub zabytków. Praktycznie rzecz ujmując dopuszczenie się popełnienia tego wykroczenia polega na działaniu w postaci stosowania paliw innych niż dopuszczone bądź o innej aniżeli dopuszczona jakości ${ }^{24}$.

Omawianą regulację trzeba ściśle powiązać z unormowaniami konstytucyjnymi zawartymi w art. 31 ust. 3 Konstytucji ${ }^{25}$, które wskazują na prawną możliwość wprowadzenia ograniczeń w zakresie korzystania z konstytucyjnych wolności i praw jednostki, a ustanawianych tylko w drodze ustawy i tylko wtedy, gdy jest to konieczne w demokratycznym państwie dla jego bezpieczeństwa lub porządku publicznego bądź dla ochrony środowiska, zdrowia i moralności publicznej albo wolności i praw innych osób. Na tle poczynionych już rozważań nie może umknąć uwadze specyfika art. 96 u.p.o.ś., na mocy którego może dojść do ograniczenia praw i wolności obywatelskich ze względu na konieczność ochrony środowiska. Ta okoliczność powinna prowadzić do ostrożnego stosowania tej regulacji w praktyce tym bardziej dlatego, że w obecnym jej brzmieniu pozostawia ona spore wątpliwości, w tym ze względu na zastrzeżenia natury konstytucyjnej. Ostrożność ta winna przejawiać się w szczególności w ścisłym użyciu art. 96 u.p.o.ś. zgodnie z zakresem wskazanym ustawowo (np. bez poszerzania kryteriów celowości podjęcia takiej uchwały czy też bez różnicowania sytuacji prawnej podmiotów). Jest to tym bardziej istotne, że w doktrynie podkreśla się, iż poddany analizie przepis głęboko ingeruje w sferę praw i wolności jednostki ${ }^{26}$. Z perspektywy standardów ograniczania praw i wolności oby-

24 Ibidem, s. 1148.

25 Konstytucja Rzeczypospolitej Polskiej z dnia 2 kwietnia 1997 r., Dz.U. z 1997 r. nr 78, poz. 483 z późn. zm.

26 K. Gruszecki, Komentarz do art. 96 ustawy - Prawo ochrony środowiska, stan prawny na dzień: 2011.06.01, LEX. 
wateli przepis ten sformułowany jest zbyt ogólnie ${ }^{27}$. Normodawca nie stanowi bowiem o ograniczeniach ani czasowych, ani merytorycznych dla zastosowania art. 96 u.p.o.ś. ${ }^{28}$. Brak również doprecyzowania określeń omówionych pokrótce wcześniej tj. sposobu realizacji i kontroli przedmiotowej uchwały. Ponadto w doktrynie podnosi się, że ogólność tego unormowania polega także na braku określenia, czy ograniczenie to może odnosić się do wszystkich czy też do niektórych tylko użytkowników środowiska ${ }^{29}$. W zasadzie, jak wynika z poczynionych już ustaleń, wystarczy tylko, aby wystąpiło negatywne oddziaływanie na środowisko lub na zabytki, co uprawniałoby organ do podjęcia tak daleko idącej w skutkach uchwały wpływającej na ograniczenie wolności i praw jednostki.

Wspomniane już nikłe zainteresowanie praktycznym zastosowaniem art. 96 u.p.o.ś. ma miejsce w głównej mierze ze względu na: brak jednoznacznych delegacji prawnych co do możliwości wprowadzenia zakazu stosowania określonych rodzajów paliw, brak skutecznych mechanizmów egzekucji i kontroli uchwały, brak uregulowań prawnych w zakresie charakteru uchwały czy brak możliwości dofinansowania kosztów eksploatacyjnych w zakresie systemów grzewczych dla mieszkańców ${ }^{30}$.

Wspomniana już Uchwała Sejmiku Małopolskiego z dnia 25 listopada 2013 r. nr XLIV/703/13, w sprawie określenia rodzajów paliw dopuszczonych do stosowania na obszarze Gminy Miejskiej Kraków, wzbudza wiele emocji, choć jej treść zawiera jedynie sześć paragrafów. Podstawę prawną ww. uchwały stanowi art. 18 pkt 1 i art. 89 ust. 1 Ustawy z dnia 5 czerwca 1998 r. o samorządzie województwa oraz art. 96 u.p.o.ś.

Paragraf pierwszy ww. uchwały wymaga w tym miejscu przytoczenia w całości: „W celu zapobieżenia negatywnemu oddziaływaniu na środowisko i na zabytki, w granicach administracyjnych Gminy Miejskiej Kraków dopuszcza się wyłącznie

27 B. Rakoczy, Komentarz do art. 96 ustawy - Prawo ochrony środowiska, stan prawny na dzień: 2013.11.25, LEX.

28 Ibidem.

29 K. Gruszecki, op. cit.

30 Z. Bukowski, op. cit., s. 45-46. 
następujące rodzaje paliw do stosowania w celu ogrzewania lokali lub budynków i przygotowywania ciepłej wody użytkowej: 1) gaz ziemny i pozostałe węglowodory gazowe przeznaczone do celów opałowych, 2) olej opałowy i olej napędowy przeznaczony do celów opałowych, z wyłączeniem ciężkiego oleju opałowego".

Paragraf drugi uchwały określa wyłączenia jej stosowania wskazując, że uchwała nie ma zastosowania do instalacji, dla których wymagane jest uzyskanie pozwolenia zintegrowanego lub pozwolenia na wprowadzanie gazów albo pyłów do powietrza w rozumieniu przepisów o ochronie środowiska.

Sposób realizacji tego aktu zawarto w § 3 uchwały. Realizacja uchwały odbywa się w szczególności poprzez:

1) wykorzystywanie w nowych lokalach i budynkach sposobów ogrzewania i przygotowania ciepłej wody użytkowej bez stosowania paliw innych niż wymienione w $\S$ 1 ;

2) dostosowanie $\mathrm{w}$ okresie od dnia wejścia w życie niniejszej uchwały, o którym mowa w $\S 6$ pkt 1) do daty określonej w $\S 6$ pkt 2), sposobu ogrzewania i przygotowania ciepłej wody użytkowej w istniejących lokalach i budynkach do wymagań określonych w $\S 1$.

Na mocy § 4 uchwały wskazano otwarty katalog organów wykonujących kontrolę realizacji uchwały, a wśród nich: Straż Miejską Miasta Krakowa, Policję, Powiatowego Inspektora Nadzoru Budowlanego w Krakowie oraz Małopolskiego Wojewódzkiego Inspektora Ochrony Środowiska ${ }^{31}$.

Jeśli zaś mowa o terminie rozpoczęcia obowiązywania przedmiotowej uchwały, w § 6 ustanowiono dwojakiego rodzaju rozróżnienie w tym zakresie. Uchwała wchodzi w życie:

1) po upływie 14 dni od dnia ogłoszenia w Dzienniku Urzędowym Województwa Małopolskiego w zakresie stosowania paliw w nowych lokalach i budynkach, tj. takich,

31 Uchwała, a więc akt prawa miejscowego, przypisuje kompetencje wskazanym w niej organom. Dokonuje się to w akcie o randze podustawowej, co nie znajduje podstaw prawnych i winno zostać ocenione jako poważne naruszenie. 
dla których wniosek o wydanie pozwolenia na budowę został złożony po tym terminie;

2) z dniem 1 września 2018 r. w zakresie stosowania paliw w lokalach i budynkach istniejących oraz lokalach i budynkach, które uzyskały pozwolenie na budowę lub dla których wniosek o wydanie pozwolenia na budowę został złożony przed terminem, o którym mowa w pkt 1).

Warto zwrócić również uwagę na uzasadnienie przedmiotowej uchwały, które jako główny cel podjęcia tego aktu wskazuje ochronę zdrowia mieszkańców oraz ograniczenie negatywnego oddziaływania zanieczyszczeń na środowisko i na zabytki dla obszaru miasta Krakowa. Wśród innych założeń dla podjęcia tego aktu nadmienia się: realizację zapisów Programu ochrony powietrza dla województwa małopolskiego oraz działanie konieczne do osiągnięcia w Krakowie jakości powietrza spełniającej dopuszczalne normy. W uzasadnieniu do przedmiotowej uchwały znajduje się również odwołanie do dwóch Dyrektyw 2008/50/WE Parlamentu Europejskiego i Rady z dnia 21 maja 2008 r. w sprawie jakości powietrza i czystszego powietrza dla Europy (CAFE) ${ }^{32}$ oraz 2004/107/WE Parlamentu Europejskiego i Rady z dnia 15 grudnia 2004 r. w sprawie arsenu, kadmu, rtęci, niklu i wielopierścieniowych węglowodorów aromatycznych w otaczającym powietrzu ${ }^{33}$. Uchwałodawca lokalny, w nawiązaniu do powołanych dyrektywy, wskazuje, że określone dyrektywami wartości dopuszczalne dla pyłów (PM10, PM2,5) oraz terminy osiągnięcia tych pułapów określonych dyrektywami transponuje do polskiego porządku prawnego Rozporządzenie Ministra Środowiska z dnia 24 sierpnia 2012 r. w sprawie poziomów niektórych substancji w powietrzu ${ }^{34}$. Uzasadniając podjęcie takiego aktu, uchwałodawca podkreśla, że w Krakowie normy jakości powietrza są rażąco przekraczane, co w konsekwencji narusza prawa do życia i ochrony zdrowia.

Jak wspomniano na początku, uchwała ta została zaskarżona do sądu administracyjnego. Wyrok Wojewódzkiego Sądu

Dz. Urz. UE L 23 z 26.1.2005, s. 3.

34 Dz.U z 2012 r. poz. 1031. 
Administracyjnego z dnia 22 sierpnia 2014 r. w sprawie o sygn. akt: II SA/Kr 490/14 ${ }^{35}$ stwierdził nieważność ww. aktu prawa miejscowego. W szerokim i rozbudowanym uzasadnieniu wyroku Sąd wskazał na motywy takiego właśnie rozstrzygnięcia odwołując się do szeregu naruszeń, do jakich doszło na tle niniejszego przypadku. U podstaw takiego rozstrzygnięcia Sądu legło przekonanie, że uchwała ta przekracza upoważnienie ustawowe określone w art. 96 u.p.o.ś. Przekroczenie to w ocenie Sądu miało wpływ na naruszenie innych przepisów w tym sensie, że zrodziło niedopuszczalną ingerencję $\mathrm{w}$ istniejących porządek prawny (wbrew zasadzie z art. 7 Konstytucji RP), realizowany zgodnie z innymi wyrażonymi w Konstytucji RP zasadami (równości i sprawiedliwości społecznej, zaufania do organów państwa $\mathrm{z}$ art. 2, wolności działalności gospodarczej z art. 20 i 22, swobody umów z art. 31 ust. 1 oraz proporcjonalności $\mathrm{z}$ art. 31 ust. 3). Ponadto, jak wynika z uzasadnienia ww. wyroku, zaskarżona uchwała została podjęta w sposób naruszający zasadę przyzwoitej legislacji ${ }^{36}$ (w tym określoności przepisów)

35 Na dzień oddania materiału do druku sprawa znajdowała się na etapie złożenia skarg kasacyjnych i skierowania sprawy na tory postępowania przed Naczelnym Sądem Administracyjnym w Warszawie.

36 Z uzasadnienia: „Także prawodawca lokalny winien stosować przepisy Rozporządzenia Prezesa Rady Ministrów z dnia 20 czerwca 2002 r. w sprawie »Zasad techniki prawodawczej« (Dz.U. nr 100, poz. 908) do aktów prawa miejscowego (czy także ich projektów), choćby z uwagi na ich znaczenie oraz wymóg zachowania spójności systemu [...]”. Tu jedynie sygnalizacyjnie należy zauważyć, że stosowanie zasad dobrej legislacji wynikające z ww. Zasad techniki prawodawczej nie ma znaczenia z perspektywy ważności czy też niepodjęcia danego aktu prawa miejscowego. W doktrynie podnosi się, że zasady techniki prawodawczej nie są wiążące dla organów stanowiących akty prawa miejscowego i winny stanowić swoistego rodzaju wytyczne stanowiące nie o ważności dokonywanych czynności prawodawczych, a o poprawności ich dokonania. Stanowiska takiego upatruje się po pierwsze w tym, że Zasady techniki prawodawczej zostały określone w akcie rangi rozporządzenia, a - jak stanowi art. 94 Konstytucji - zasady i tryb wydawania aktów prawa miejscowego winna określać ustawa. Po wtóre uzasadnione zastrzeżenie budzi także zgodność treści tego rozporządzenia z upoważnieniem ustawowym, na podstawie którego zostało ono wydane (mianowicie na podstawie art. 14 ust. 5 i 6 Ustawy z dnia 8 sierpnia 1996 r. o Radzie Ministrów), ze względu na umieszczenie w nim także zasad dotyczących stanowienia prawa przez organy nie będące organami administracji rządowej. Zarys metodyki pracy legislatora. 
oraz zasadę zaufania obywateli do państwa i prawa. Naruszenia zasad przyzwoitej legislacji Sąd upatruje w nieprecyzyjnym i niejasnym określeniu adresata uchwały, jak również wzorca powinnego postępowania ${ }^{37}$. Podnosi się, że nie tylko treść normatywna samej uchwały, ale również jej uzasadnienie - brane pod uwagę przy rozstrzyganiu przedmiotowej sprawy - nie zawiera jasnych wytycznych interpretacyjnych umożliwiających ustalenie adresata norm w niej zawartych. Sąd zauważa, że naruszeniem Konstytucji RP jest stanowienie przepisów niejasnych, wieloznacznych, niepozwalających jednostce przewidzieć konsekwencji prawnych jej zachowań (tak: Trybunał Konstytucyjny w Wyroku z dnia 22 maja 2002 r. K 6/02, OTK ZU 2002, nr 3/A/2002, poz. 33, s. 448). Takie właśnie negatywne cechy charakteryzują zaskarżoną uchwałę, niezależnie od naruszenia zasad techniki prawodawczej ${ }^{38}$. Ponadto jako kolejny z argumentów przytaczanych przez Sąd, przemawiającym za tworzeniem przepisów czytelnych i nie budzących wątpliwości, jest powiązanie art. 96 u.p.o.ś. ze stosowaniem sankcji karnej wynikającej z treści art. 334 u.p.o.ś. Na marginesie wypada zauważyć, że Sąd przyjmuje prymat wykładni literalnej - co znajduje wyraz m.in. w szczególnie rozbudowanym odwoływaniu się do różnorakich definicji ustawowych i tłumaczeniu pojęć zawartych w uchwale - uzasadniając swe stanowisko faktem, że skorzystanie z kompetencji zawartych w art. 96 u.p.o.ś. może doprowadzić do ograniczenia praw i wolności obywatelskich, $\mathrm{w}$ tym zastosowania sankcji karnej przewidzianej w art. 334 u.p.o.ś. Sąd wskazuje również, że art. 96 u.p.o.ś. nie powinien być stosowany jako instrument osiągania doraźnych efektów, nawet w imię ważnych społecznie celów, zwłaszcza kosztem tyl-

Ustawy. Akty wykonawcze. Prawo miejscowe, red. A. Malinowski, Warszawa 2009, s. 223 i n.

37 Klarowne określenie wzorca postępowania nabiera szczególnie istotnego znaczenia w sytuacji, gdy za naruszenie tego wzorca grożą sankcje karne lub innego rodzaju konsekwencje mogące wkraczać w sferę praw i wolności jednostki, jak to ma miejsce w rozważanym przypadku.

38 Sąd podkreśla również, że uchybienia, jakich dopuścił się organ uchwałodawczy w zakresie zasad prawidłowej legislacji, nie stanowią podstawy do stwierdzenia nieważności aktu prawa miejscowego. 
ko niektórych osób, i to poprzez nakładanie na nie obowiązków finansowych, których niewykonanie jest zagrożone możliwością wielokrotnego stosowania sankcji karnej, względnie także innymi negatywnymi konsekwencjami, które można wywołać i egzekwować poprzez dowolne kształtowanie nakazów dotyczących sposobu realizacji i kontroli zaskarżonej uchwały ${ }^{39}$. Nadto literalna interpretacja art. 96 u.p.o.ś. wymusza stosowanie przewidzianych w nim możliwości tylko w sytuacjach wyjątkowych i na zasadach równego traktowania podmiotów.

Sygnalizacyjnie należy również odnotować stanowisko Sądu przyjmujące, że w tym przypadku zastosowania nie znajdzie Dyrektywa 98/70/WE Parlamentu Europejskiego i Rady z dnia 13 października 1998 r. odnosząca się do jakości benzyny i olejów napędowych ${ }^{40}$. W ocenie Sądu wyżej wskazana dyrektywa dotyczy innych zagadnień aniżeli te wynikłe na tle przedmiotowej uchwały, gdyż dyrektywa ta ustala specyfikacje techniczne z powodów związanych ze zdrowiem i środowiskiem mające zastosowanie do paliw przeznaczonych do użytku w pojazdach wyposażonych w silniki z zapłonem iskrowym i silniki z zapłonem samoczynnym ${ }^{41}$.

W tym miejscu też należy poczynić potrzebną - z perspektywy dalszej części artykułu - dygresję na temat swobody $\mathrm{w}$ zakresie stanowienia przez organy samorządowe aktów prawa miejscowego. Należy mieć także na względzie samodzielność jednostek samorządu terytorialnego wynikającą z art. 165 ust. 2 ustawy zasadniczej. Zgodnie z art. 94 Konstytucji RP ustanawianie aktów prawa miejscowego obowiązujących na obszarze działania organów dokonuje się na podstawie i w granicach upoważnień zawartych w ustawie. Ponadto zasady i tryb wydawania aktów prawa miejscowego określa ustawa. Stanowienie aktów prawa miejscowego, jakkolwiek o dużym zakresie swobody, nie może być dowolne. Akty prawa miejscowego są aktami wykonawczymi do ustawy w szerokim tego słowa zna-

39 Na marginesie należy zauważyć, że żadna jednostka redakcyjna uchwały nie zawiera w swojej treści sformułowań „nakazuje” czy „zakazuje”.

40 Dz. Urz. UE L 350 z 28.12.1998, s. 58-68.

41 Por. M. Górski, M. Pchałek, W. Radecki, J. Jerzmański, M. Bar, S. Urban, J. Jedrośka, op. cit., s. 373 i n. 
czeniu: służą wykonywaniu ustawy w tym sensie, że muszą być zgodne z celami ustawowych upoważnień i nie mogą przekraczać wyznaczonych przez ustawy granic ${ }^{42}$. Organ uchwałodawczy jednostki samorządu terytorialnego, kierując się potrzebami lokalnymi w stanowieniu aktów prawa miejscowego, nie może ich podejmować w oderwaniu od zasad prawa, a więc nie może zapominać o wymogu zgodności tworzonego prawa lokalnego zarówno z Konstytucją, jak i ze wszystkimi aktami rangi ustawowej. Działalność prawotwórcza samorządu terytorialnego musi więc odbywać się de facto w myśl zasady „dozwolone jest to, co prawo wyraźnie przewiduje”, a nie według zasady, że „dozwolone jest to, co nie jest zakazane"43.

W zakresie pozostającym $\mathrm{w}$ polu zainteresowania tego artykułu należy odnieść się do następujących regulacji wskazanych jako podstawę podjęcia omawianej uchwały: art. 18 pkt 1 i art. 89 ust. 1 Ustawy o samorządzie województwa oraz art. 96 u.p.o.ś. W świetle art. 18 pkt 1 do wyłącznej właściwości sejmiku województwa należy stanowienie aktów prawa miejscowego. Zgodnie zaś z brzmieniem powołanego art. 89 ust. 1 na podstawie tej ustawy oraz na podstawie upoważnień udzielonych w innych ustawach i w ich granicach sejmik województwa stanowi akty prawa miejscowego obowiązujące na obszarze województwa lub jego części.

Oceny czy skarżona uchwała została podjęta w granicach ustawowych należy dokonać ściśle przez pryzmat art. 96 u.p.o.ś., który to determinuje ostateczny zakres uchwały sejmiku województwa. W treści art. 96 u.p.o.ś. wskazuje się, że uchwała ta podejmowana jest „w celu zapobieżenia negatywnemu oddziaływaniu na środowisko lub na zabytki". Zaskarżona uchwała w przytoczonym już wcześniej § 1 wprowadza dodatkowe, nieprzewidziane $\mathrm{w}$ ustawie określenie dotyczące celowości, a mianowicie: „w celu ogrzewania lokali lub budynków i przygotowania ciepłej wody użytkowej”. Taka konstrukcja treści uchwały przekracza granice normatywnego zakresu wynikającego z upo-

42 Zarys metodyki pracy legislatora. Ustawy. Akty wykonawcze. Prawo miejscowe, s. 209.

43 Ibidem, s. 210. 
ważnienia ustawowego zawartego w art. 96 u.p.o.ś. Ponadto różnicuje sytuację prawną podmiotów i niedopuszczalnie modyfikuje zakres przedmiotowy uchwały zawężając go tylko do sytuacji ogrzewania lokali, budynków i przygotowania ciepłej wody użytkowej. Tymczasem - co wymaga szczególnego podkreślenia - art. 96 u.p.o.ś., jako jedyne kryterium różnicowania, przyjmuje terytorium, na którym ma obowiązywać uchwała. Ustawodawca nie wprowadza innych przesłanek uzasadniających różnicowanie sytuacji podmiotów w zależności od: przynależności do pewnej ich grupy (np. jednostki posiadające czy też nieposiadające pozwolenia) lub sytuacji (np. ogrzewanie lokali lub przygotowanie ciepłej wody użytkowej). W istocie więc art. 96 u.p.o.ś. stawia nacisk na skalę oddziaływania oraz rodzaj oddziaływania, a nie na to kto i w jakim celu używa paliwa danego rodzaju albo paliwa określonej jakości. Zatem i w tym przypadku brak zrozumiałych, a przede wszystkim prawnych, podstaw wskazania dodatkowych kryteriów celowości podjęcia ww. uchwały czy też określenia innych, aniżeli wynikające wprost z przepisu, przesłanek dla różnicowania sytuacji podmiotów. Skoro zaś sejmik przekroczył upoważnienie ustawowe, to tym samym uchwała, jako wydana bez takiego upoważnienia, winna zostać uznana za nieważną.

Sąd w uzasadnieniu do przedmiotowego wyroku zauważa również poważne trudności powstające przy określeniu adresata uchwały, które w konsekwencji zmuszają do podjęcia skomplikowanej interpretacji i analizy uchwały. Zaprezentowany w uzasadnieniu pogląd nie opiera się na założeniu, zgodnie z którym katalog adresatów uchwały ma być enumeratywny, a jedynie podkreśla się, że wskazanie to powinno odbyć się w taki sposób, aby nie powstawały wątpliwości kto jest adresatem uchwały oraz, aby nie było wymagane dokonywanie skomplikowanej wykładni w celu ustalenia kogo ta uchwała dotyczy. Co równie ważne i winno być podkreślone, cechą przepisów prawa miejscowego jest to, że normy te skierowane są do nieokreślonego kręgu podmiotów ${ }^{44}$. Przyjmuje się, że akt prawa miejscowego -

44 Por. Wyrok NSA z dnia 19 sierpnia 2010 r. w sprawie sygn. akt: II OSK $1159 / 10$ 
a takim jest przecież omawiana uchwała - to akt normatywny o charakterze generalnym i abstrakcyjnym. Normatywny charakter oznacza, że akt ten zawiera wypowiedzi wyznaczające adresatom pewien sposób zachowania się, przybierający postać nakazu, zakazu lub uprawnienia. Charakter generalny zaś oznacza, że normy zawarte $\mathrm{w}$ akcie definiują adresata poprzez wskazanie cech, a nie poprzez wymienienie ich z nazwy. Abstrakcyjność normy wyraża się więc w tym, że nakazywanie, zakazywanie lub dozwolone zachowanie ma mieć miejsce w pewnych, z reguły powtarzalnych, okolicznościach, nie zaś w jednej konkretnej sytuacji ${ }^{45}$. Zastosowanie takiej techniki legislacyjnej - wymagającej złożonych analiz w celu ustalenia adresata aktu - z pewnością nie pozostaje w zgodzie z zasadą zaufania obywateli do państwa i prawa. Prawodawca lokalny powinien kształtować normy prawne w sposób jasny, precyzyjny, w szczególności poprzez określenie adresata uchwały, co ma istotne znaczenie w sytuacji, gdy za niedostosowanie się do postanowień uchwały przewiduje się sankcje prawne ${ }^{46}$.

Jedynie sygnalizacyjnie należy zauważyć, że w lutym 2015 r. ukazał się poselski projekt zmian artykułu 96 u.p.o.śs7. W świetle proponowanej treści art. 96 ust. 1 u.p.o.ś miałby

45 Opracowanie dotyczące normatywnego i abstrakcyjnego charakteru aktu prawa miejscowego w oparciu o Wyrok NSA z dnia 19 sierpnia $2010 \mathrm{r}$. w sprawie sygn. akt: II OSK 1159/10 oraz Wyrok NSA z dnia 7 października 2014 r. w sprawie sygn. akt: II OSK 846/14.

46 Tak Wyrok Trybunału Konstytucyjnego z dnia 22 maja 2002 r. K 6/02, OTK ZU 3/A/2002, poz. 33, s. 448.

47 http://orka.sejm.gov.pl/Druki7ka.nsf/Projekty/7-020-1250-2015/\$file/7-020-1250-2015.pdf [dostęp: 09.03.2015 r.] Przedłożony projekt przewiduje następujące brzmienie art. 96 u.p.o.ś.: „1. Sejmik województwa może, w drodze uchwały będącej aktem prawa miejscowego, w celu zapobieżenia negatywnemu oddziaływaniu na środowisko lub na zabytki, wprowadzić ograniczenia lub zakazy w zakresie eksploatacji instalacji i urządzeń, w których następuje proces spalania.

2. Uchwała, o której mowa w ust. 1, określa:

1) granice obszaru objętego ograniczeniami lub zakazami;

2) rodzaje lub jakość paliw dopuszczonych do stosowania lub zakazanych do stosowania;

3) parametry techniczne lub parametry emisji dopuszczonych do stosowania instalacji i urządzeń, w których następuje spalanie paliw; 
brzmieć następująco: „Sejmik województwa może, w drodze uchwały będącej aktem prawa miejscowego, w celu zapobieżenia negatywnemu oddziaływaniu na środowisko lub na zabytki, wprowadzić ograniczenia lub zakazy w zakresie eksploatacji instalacji i urządzeń, w których następuje proces spalania".

Względem aktualnie obowiązującej treści proponowana zmiana wprowadza następujące modyfikacje: w nowym brzmieniu dodaje się określenie charakteru prawnego uchwały sejmiku województwa (,w drodze uchwały będącej aktem prawa miejscowego"), wyeliminowuje zakres terytorialny (tj. treść „dla terenu województwa bądź jego części”48) oraz przekształca się obecnie obowiązujący przepis in fine zmieniając zapis „rodzaje lub jakość paliw dopuszczonych do stosowania, a także sposób realizacji i kontroli tego obowiązku” na „wprowadzić ograniczenia lub zakazy w zakresie eksploatacji instalacji i urządzeń, w których następuje proces spalania". Ponadto w nowym brzmieniu art. 96 uzyskuje dalsze ustępy, a mianowicie: ust. 2-3 - dotyczące elementów fakultatywnych i obligatoryjnych uchwały podejmowanej na podstawie art. 96 ust. 1 oraz ust. 4 - będący wskazaniem jaki pojazd w rozumieniu ustawy winien być uważany za pojazd uprzywilejowany.

Uzasadnienie projektu wskazuje, że zmiany te mają na celu doprecyzowanie uregulowań i rozwiązanie wątpliwości

4) obowiązki podmiotów objętych uchwałą oraz organów administracji publicznej w zakresie niezbędnym do kontroli realizacji uchwały.

3. Uchwała, o której mowa w ust. 2, może także określać:

1) sposób wykorzystania paliw, który jest objęty ograniczeniami określonymi w uchwale;

2) okres obowiązywania ograniczeń lub zakazów w ciągu roku lub warunki meteorologiczne lub stan jakości powietrza, dla których obowiązują ograniczenia lub zakazy określone w uchwale;

3) wyłączenia z ograniczeń lub zakazów określonych w uchwale dla pojazdów należących do mieszkańców obszaru, o którym mowa w ust. 2 pkt 1 i pojazdów uprzywilejowanych.

4. Pojazdy uprzywilejowane, o których mowa w ust. 3 pkt 3 i w art. 96b ust. 3, są to pojazdy pogotowia ratunkowego, straży pożarnej, pogotowia gazowego, policji".

48 Określenie zakresu terytorialnego dla omawianej uchwały zawarte zostało w proponowanej treści art. 96 w ust. 2 pkt 1. 
prawnych celem elastycznego zastosowania tego instrumentu. Jednak nowe brzmienie art. 96 u.p.o.ś. niewiele zmienia w zakresie oceny konstytucyjności wskazanego przepisu. Należy podkreślić, że projekt ten zdecydowanie rozbudowuje treściowo (objętościowo) art. 96 u.p.o.ś., choć nie da się ukryć, że nie usuwa dotychczasowych wątpliwości. Wydaje się, że autorzy projektu poselskiego nie skupiają się na meritum problemu, a więc na zarzutach podnoszonych w doktrynie, dotyczących konstytucyjności takiego - ogólnego - rozwiązania, mocno ingerującego w sferę praw i wolności jednostki. Jak już wspomniano, główne zarzuty dotyczą zbytniej ogólności tego uregulowania w szczególności z perspektywy braku zawarcia w nim ograniczeń czasowych, co do obowiązywania uchwały ${ }^{49}$ czy braku wskazania, które określałoby, czy ograniczenia lub zakazy zeń wynikające mają odnosić się do wszystkich podmiotów, czy też tylko do niektórych ich kategorii. Projekt zdaje się nie dostrzegać problemu u źródła, wobec czego nie uszczegółowia i nie uzupełnia tej regulacji we wspomnianym powyżej zakresie. Szczególnie istotnym elementem, jaki winien znaleźć się w przedmiotowej regulacji, jest określenie względem jakich podmiotów/użytkowników środowiska uchwała ta powinna mieć zastosowanie. Takie rozwiązanie wydaje się być racjonalne i bezpieczne po pierwsze w kontekście uniknięcia sytuacji, gdy koniecznym jest dokonywanie złożonej interpretacji celem ustalenia adresata uchwały, a po wtóre w kontekście ważkiej kwestii, tj. szeroko pojętej zasady równości podmiotów względem prawa. Skupiono się na kwestiach ważnych, choć - z perspektywy podniesionych powyżej uwag - drugorzędnych. Zauważyć wypada, że w projekcie przewiduje się również wprowadzenie nowych rozwiązań prawnych. W świetle dodanego w projekcie poselskim art. 96a upoważnia się władze lokalne, tj. radę gminy, do podjęcia uchwały będącej aktem prawa miejscowego, wprowa-

49 Choć jakimś wyjściem jest tu fakultatywny element uchwały wskazany w art. 96 ust. 3 pkt 2 proponowanych zmian (tj. „okres obowiązywania ograniczeń lub zakazów w ciągu roku lub warunki meteorologiczne lub stan jakości powietrza, dla których obowiązują ograniczenia lub zakazy określone w uchwale"). 
dzającej strefę ograniczonej lub zakazanej emisji z transportu. Szczegółowe rozważania na ten temat pozostają jednak poza założonymi ramami niniejszego artykułu.

Nie ulega wątpliwości, że przewidziane prawne możliwości wynikające z art. 96 u.p.o.ś. są potrzebne celem ochrony środowiska i ochrony zabytków. Jednakże zarówno obecne brzmienie, jak to i zawarte $\mathrm{w}$ projekcie poselskim z lutego $2015 \mathrm{r}$. nie daje podstaw, aby podjęta na ich mocy uchwała ostała się w obrocie prawnym. Spowodowane jest to ciągłymi wątpliwościami (w tym natury konstytucyjnej) związanymi z prawnymi aspektami zastosowania art. 96 u.p.o.ś. Teoretycznie więc istnieje możliwość podjęcia takiej uchwały (ze względu na szczegółowo uzasadnione przesłanki), jednakże rozliczne wątpliwości, rodzące się na tle podstawy prawnej uchwalenia tego aktu prawa miejscowego, w praktyce mogą skutkować powstaniem dużego ryzyka skierowania sprawy na tory postępowania sądowo-administracyjnego. Ze względu na daleką ingerencję w sferę wolności i praw podmiotów wynikającą z przedmiotowej regulacji, art. 96 u.p.o.ś. wymaga należytego doprecyzowania i zmiany oraz szczególnej staranności prawodawcy, który wyważy niezwykle cienką granicę pomiędzy interesem publicznym a interesem strony z uwzględnieniem ochrony środowiska.

\section{BIBLIOGRAFIA}

Bukowski Z., Możliwości prawne wprowadzenia zakazu spalania określonych paliw stałych na terenie gminy, „Studia z zakresu prawa, administracji i zarządzania UKW" 2012, t. 1.

Górski M., Pchałek M., Radecki W., Jerzmański J., Bar M., Urban S., Jedrośka J., Prawo ochrony środowiska. Komentarz, Warszawa 2011.

Gruszecki K., Komentarz do art. 96 ustawy - Prawo ochrony środowiska, stan prawny na dzień: 2011.06.01, LEX

Informacja o wynikach kontroli, Ochrona powietrza przed zanieczyszczeniami, $\quad$ 01.12.2014r., http://www.nik.gov.pl/plik/ id,7764,vp,9732.pdf [dostęp: 03.03.2015 r.] 
Projekt poselski zmian u.p.o.ś. z lutego 2015 r. http://orka. sejm.gov.pl/Druki7ka.nsf/Projekty/7-020-1250-2015/\$file/7-020-1250-2015.pdf [dostęp: 09.03.2015 r.]

Rakoczy B., Komentarz do art. 96 ustawy - Prawo ochrony środowiska, stan prawny na dzień: 2013.11.25, LEX.

Zarys metodyki pracy legislatora. Ustawy. Akty wykonawcze. Prawo miejscowe, red. A. Malinowski, Warszawa 2009.

Kontakt e-mail:

ewaolejarczyk@vp.pl 